\title{
Shura and Pluralism from an Islamic Perspective "Jordanian Parties, as a Model"
}

\author{
Abdalhaleem Al-Adwan ${ }^{1}$ \\ ${ }^{1}$ Associate Professor of Political Science, Vise Dean of Faculty of Islamic Architecture \& Arts, College of Arts \\ and Sciences, The World Islamic Sciences and Education University, Jordan
}

Correspondence: Abdalhaleem Al-Adwan. E-mail: dr.abdalhaleem6@yahoo.com

Received: March 9, 2020

Accepted: May 10, $2020 \quad$ Online Published: December 30, 2020

doi:10.5539/ass.v17n1p62

URL: https://doi.org/10.5539/ass.v17n1p62

\begin{abstract}
Shura and pluralism are two sides of ideologically different ideas, Islamic thought that adopts the Shura as an Islamic democratic system and Western thought embraces political pluralism. As for the Jordanian Islamic trend, since its establishment in 1945, it has been involved in political work and supported the system of government in facing the challenges it faced, and it was not involved in any subversive or terrorist acts. After 1989 he began participating in political and party pluralism, seeing Shura's concept as a feature of Islamic thinkers and thought in pluralism and democracy. That pluralism is a permissible and legitimate interest, has coexisted with left and middle political currents being the largest and most influential political currents on the Jordanian scene.
\end{abstract}

Keywords: Shura, pluralism, Islam, Jordanian parties

\section{Introduction}

The Muslim Brotherhood was founded in 1945 as the nucleus of the Islamic trend in Jordan. Its political role in society has evolved in multiple stages; it has expanded in the concept of Shura and the view of pluralism in Islamic work as a matter of legitimate interest while supporting the regime in its stages of danger by the left parties, Jordanian Islamic parties are no different from Islamic parties in the world. Since its establishment in the fourth decade of the twentieth century, it has opposed the political system without participating in any terrorist or subversive act, and it sees that pluralism is a Western system that is not compatible with the Islamic Shura system even though it participated in the first multi-party elections in 1956 and did not participate in the party government.

As a result of the democratic transformation in the political system in 1989, Jordanian Islamic parties participated in the parliamentary elections and multi-party and political pluralism with other faith parties. And because Shura is a pillar of thought and political action in Islam, it is the basis of social relations, including economic, financial, cultural, and other relations, and the relations between groups, bodies, and sects that go into forming the nation (Arabiyat: Al-Rai newspaper 2009).

Therefore, the expansion of Shura's concept has been tackled widely by Islamic scientists and the feature of Islamic thought in parliamentary democracy and pluralism. Also, Islamist groups and parties see political pluralism as a political framework and work to spare peoples from revolutionary and dictatorial regimes' negative aspects.

\subsection{The Importance of the Study}

The importance of research stems from many studies. That dealt with political pluralism The Islamic movements in Jordan had very little that might have dealt with an aspect of Shura and political pluralism. The study also acquires its importance through its participation with the political system and other political parties to achieve political pluralism.

\subsection{Study Objectives}

1. Identify t the political stages that the development of Islamic party work has gone through and the extent to which Islamist parties accept this transformation and make room for pluralism and democracy.

2. To show the extent to which Islamist parties and movements accept to participate with other currents and parties in the political pluralism transformation. 


\subsection{Study Problem}

Islamic parties face internal and external challenges because of their political pluralism and democracy, as they contravene the Shura in the Islamic system. To meet the challenges, it became necessary to know the expansion of Shura's concept as a starting point for these parties' ideas of democracy and pluralism.

\subsection{The Study Hypothesis}

There is a correlation between internal and external transformations to introduce political pluralism and between Jordanian Islamic parties' transformations to participate in political pluralism in Jordan.

\subsection{Definition of Political Parties}

The definitions of political parties varied due to the different political trends, and the difference in reports is due to the multiplicity of ideologies, the view of these trends towards the functions of the parties, and the angle from which these parties are seen. The different definitions came to express the adoption of several civilizations for the parties. That reflected the thought and social reality in which she lived (Doverje, 1992, pp. 72-74).

Some define the party socially, such as Samuel Eldersveid as: "A social organization that carries out activities for the benefit of the group, which means that individuals have their roles within the social unit and they work to achieve specific goals" (Samue, 1964, p. 47).

Leon Depstein defines the party as: "A group, no matter how poorly organized, working to elect those with official positions based on a well-known slogan. Accordingly, any group that works to attain official positions in the state and its members seek to do so may be called a party (Leon, 19467, p. 22).

Some focus on defining the party on the practical side and the ultimate goal of the political process on which the party is based, such as liberal thought. Admon Burke defines it: "The party is a union between a group of individuals to work together to achieve the national interest by specific principles agreed upon by all" (Al-Khatib, 20: 1983), and there are those who focus on defining the party on the class side and concentrate on the social formation and economic linkage between its members such as the Marxist socialist thought (Zoubi 88: 1995).

As for Arab thought, we find that jurists' definition of a political party is close to liberal thought. Suleiman Al-Tamawi defines it: "It is a united group of individuals working with various democratic means to win judgment with the intent to implement a specific political program (Al-Tamawi, 569: 1979)."In Jordan, the Jordanian Political Parties Law of 1992 did not depart from the political party's definition from liberal and Arab thought. The political party defines (the Parties Law of 2015), "That every political organization consists of a group of Jordanians by the constitution and the provisions of the law to participate in political life and achieve specific goals related to political, economic and social affairs, and it works by legitimate means." And it is noted from the previous definitions that they differ from the definition of the political party in the Jordanian Parties Law. Most definitions indicate that the party is seeking to gain power; that is, it believes in the theory of the transfer of power by legitimate and peaceful means. The Jordanian parties law did not refer to the principle of the transfer of power or reach judgment, but rather it referred to participation in political life. Therefore, we believe that the definition of the political party in Jordan should be consistent with the definition that focuses on the common goal that individuals seek through the party to avoid thinking about illegal means, parties and political forces may turn to it.

\section{Shura and Political Pluralism}

In Islamic thought, political pluralism did not appear as a specific term as it appeared in Western political thought. However, the (Shura) principle appeared as a term indicating "political pluralism and democracy participating in the Arab-Islamic civilization." It is an Islamic democratic term (Dajani 29: 1989).

Islam also defined the basic rules upon which Shura's principle is based, and Islamic law has approved general policy provisions, with social, economic and cultural connotations related to worldly and human affairs of the present and future. It is linked to Islamic morals, ideals, and higher values, as mentioned in the Qur'an and Sunnah. Within this framework, and the expansion of the concept of Shura has become a modern Islamic thinker, and the feature of Islamic thought in a democracy, parliamentary, and pluralism, and giving it the new contemporary political implications to emphasize that the Islamic heritage includes many contemporary democratic concepts (Badran 49: 1989) and pluralism.

This does not mean accepting the Western democratic system, but rather, it is taken from it the fundamental values that agree with the Shura. In contemporary history, we find that some Islamic movements, including those in Jordan, call for the introduction of political pluralism, but within the main principles are (Al-Farhan, 1996: 74-75) that God created people different and disparate, peoples and tribes of their characteristic cooperation and 
acquaintance, therefore, they see that the multiplicity of religions, ideologies, doctrines and political parties are commensurate with the nature of creation, so everyone has the freedom to believe and think. Just as God created people who are similar in creation and kind, and differences in physical and mental energies, in which individual and group differences emerge, and the difference in individuals' thinking and attitudes is highlighted, so it is natural for the legitimacy of political and party pluralism to emerge in the human endeavors of solutions, alternatives, and propositions aimed at achieving the agreed goals. And as long as Islam is an ideology, thought, and civilization, Islam is the identity and culture of Arabs and Muslims. There is no objection to adopting political or partisan pluralism that does not call for changing the nation's identity and ideology.

In the same context, Islamic groups and parties, especially in Jordan, find political pluralism a political framework that avoids peoples from the negative aspects of revolutionary and dictatorial regimes. "The experience of political pluralism in contemporary societies has proven to be the appropriate peaceful means for the transfer of power without imposing on the people the negative aspects of military coups or popular revolutions that lead to bloodshed and internal warfare between people.

This matter is considered a legitimate policy that depends on a balance between bringing interests and ward off evil. And that the legal basis in customs and transactions is the solution, not the prohibition, because political pluralism in contemporary Islamic work it is viewed as a matter of legitimate interest of halal matters (Al-Farhan, February 25: 1996).

\subsection{Definition of Political Pluralism}

Several definitions have been mentioned in several studies (Al-Adwan, 2008, pp. 35-39) for the concept of pluralism in general and political pluralism in particular. Although there is no clear definition of political pluralism, the general definitions attempt to link pluralism and the political system, state, and law components. On the one hand, political pluralism focuses on the diversity and difference between the constituent groups of society; on the other hand, the framework that determines social and political relations in society is the sovereign state. Therefore, political pluralism means (Dajani, 1990, pp. 1-95).

Distributing power within a society that consists of diverse groups that control conflict, competition, or cooperation equally among themselves also refers to the governmental authority institution and participating in civil society organizations or participating in the authority. On the social side, "political pluralism is essentially a recognition of the legitimacy of social pluralism, and the right of society to form differences, and each endeavor to defend their legitimate interests in a peaceful framework that recognizes the same right to other formations by rules that everyone respects (Prince Hassan, 9: 1989).

The concept and definition of political pluralism, as is common in the literature of social sciences, was also adopted by the Arab Thought Forum committee, to "the legality of the multiplicity of forces and political opinions and their right to coexist, express themselves and participate in influencing the political decision in their society." And perhaps the essential expression of this concept is reaching that political pluralism is the essential pillar of democracy. Still, it cannot be equated with democracy in its traditional sense; the most critical pillar of pluralism is the actual political competition that results in an elite group of people and leaders. Political pluralism's success depends on the manifestations of multiple political parties (Barakat 1992: 281-282). Among them is confidence that enables them to reach this success in the coming times if they exclude the risks and sensitivity of the competition that is generated through their pursuit of political positions among themselves. This gives her the right to legitimate opposition, select its candidates, and formulate its programs through open channels of communication with public opinion. This is not proven by Western liberal democracy based on partisan pluralism (Al-Hamd, 1992, p. 192). That moves within the political system legitimately to achieve its goals, despite their ideological differences.

The actual concept of political pluralism within a democratic transition requires that party pluralism be allowed (Thabet, 1981, p. 54) without restrictions, and allow free competition between the parties and their candidates to reach power and parliament seats and the peaceful transfer of power between them. It would seem that. "Pluralism" means party pluralism, that is, the multiplicity of political parties in society, but it is considered the most critical political pluralism pillar initially.

\subsection{The Concept of Political Pluralism}

The concept of pluralism (aggression, 2008, pp. 33-44) is broad and manifold, based mainly on diversity and difference. Pluralism may be political, social, cultural, or religious, while pluralism in societies takes two primary forms (Al-Kuwari, 1993, p. 60). The first is traditional pluralism, such as (religious, sectarian, linguistic, tribal, and community origin). The second is a modern plurality, such as plurality (intellectual, regional, class). 
The concept of political pluralism first appeared through the opinions and theories of thinkers and philosophers in Europe in the sixteenth century in determining the type of government, state, power, and sovereignty, in reaction to the powers of the dictatorial and unilateral state and the supremacy of absolute power that are the antithesis of democracy and political pluralism, they later became the ideas of John Locke and Jean-Rousseau.

More suitable for political, intellectual development and the development of the concept of political pluralism and reinforced by a new principle closer to research on the issue of political pluralism which is the theory of French thinker Charles Montesquieu 1715 (Desouki, 1973: 226-240), based on the separation of legislative and executive powers, the pluralistic picture is complete and precise after the arguments of the American thinker (Dunleavy, 1982: 14-15) (James Madison)Who believes that the only way to bypass the provision of personal interests is to establish institutions of the political community based on balance and control among these institutions. And this is achieved by separating the three powers by a vertical separation and horizontal division through the principle of federalism. So we see that the concept of pluralism in capitalist Western Europe has gradually evolved. We did not find this phased progression of political pluralism and democracy in the communist and developing countries and the Arab states: If we exclude the countries that converted to democracy and the imposed pluralism from the colonial governments and America in particular, after defeating totalitarian and dictatorial regimes.

\section{Stages of Development of Jordanian Parties}

Although the establishment of political parties coincided with the establishment of the Emirate of Transjordan in 1921, there were no Islamic political parties until 1945. It drew the evolution of its political participation with other political parties in the left-wing and nationalist trend and the conservative current and their presence on the Jordanian scene in public, sometimes, and secretly at other times, and political developments and events influence it in Jordan and the surrounding regional region, and external influences (Assaf, 25: 1998), since the unity between the two banks and the adoption of the 1952 constitution until now.

\subsection{The Positions of the Islamic Movement from Participation and Political Pluralism}

The Islamic trend is the oldest in the history of the Arab region, and it enjoys great public support in Jordan. The Islamic trend is based on its approach to Islamic action in general and political action, particularly from the following assumptions: Islam is a comprehensive message. It is a doctrine, Sharia, and a system of life, not just religion in the Western priestly sense, and politics is part of religion, and religion uses politics as one of the mechanisms in managing and reforming societies to achieve the purposes of Sharia. Islamic work must be comprehensive in all aspects of life, such as belief, worship, economics, meeting, administration, and politics.

Islamic political action takes all the moral mechanisms and means that are consistent with the lofty goals of the Islamic message, and that these methods adopt the method of advocacy, which is better, with wisdom, dialogue, peaceful means, adopting Shura and democracy, and rejecting violence and terrorism or using force. (Al-Farhan, 1996, pp. 63-65). Some Islamists believe that a Muslim must arm himself with political awareness as a guide to the new Muslim path and make it a qualitative and festive addition to society in light of the constitution, law, and democratic systems of government. And Islamic organizations must take advantage of the margin of freedoms permitted by these regimes, such as the Jordanian regime. Politics in practice is leadership, and the Muslim's departure from politics means that he will voluntarily give up participating in leadership. So, the Islamic movement permits political action and political participation (Al-Akour 85: 2004).

\subsection{Islamic Parties and Political Pluralism}

Three major trends have emerged in the Islamic movement on the topic of political participation in government or parliament (Clinics, 1997, pp. 143-144), and every direction differs from the other: the first: prohibits participation and considers it a dilution of the issue for the masses, because the ruling without what God revealed is invalid. The second direction: sees planning. This means that the form of participation is alien to the Islamic sense, and it is a Western capitalist system. It is not permissible to participate except for the necessities of notification and advocacy in filling all other means, but without participating in the ruling or enacting laws and regulations that contradict Sharia. And the third direction: He sees the permissibility of absolute participation and does not benefit from boycotting it as it is possible to benefit Muslims and block the way to religion's enemies.

While some Islamists believe that the atmosphere of freedom that was available in 1956 and 1989 provided an opportunity for the progress of the Islamic movement towards the transformation of democratic participation and political pluralism, the Islamic movement allowed working with other parties and forces through coordination and searching for standard features, and cooperation in developing a national pact with all political groups, and coordination for the development of the law of parties. Thus, the concepts of pluralism were firmly established 
intellectually, dynamically, and in reality in the Islamic movement. Because as long as the science of jurisprudence permits the difference in opinion within a single thought, we cannot deny it, "then we accept political pluralism (Arabiyat, 131-132)."

Some Islamic leaders confirm this by saying, as long as the religion of the state is Islam, and Islam is an ideology and civilization of citizens, so it is not permissible to change the identity of the nation due to the claim of partisan or political pluralism, where pluralism is in programs, means, and mechanisms, not in the interpretation of a new religion. Thus, political pluralism is an essential feature of the practice of democracy. Partisan pluralism is a modern manifestation of democracy, and that freedom of opinion and expression is another manifestation of democracy, as well as political pluralism means freedom of political practice within the laws in force and without discrimination, it also gives rise to the right to establish political parties with specific political programs within the constitution and applicable laws (Al-Rabie ', 2004, pp. 67-64).

\subsection{Formation of a Pluralistic Map of Islamic Parties}

Before delving into the map of an Islamic multi-party system, it is necessary to mention the map of a multi-party system in Jordan. Since the beginning of the democratic transformation and political pluralism in 1989, and the issuance of the Political Parties Law of 1992, political parties began to appear in Jordanian political life in public: some of them remained and continued. Some of them disappeared shortly after its licensing. Including what joined with other parties in political unity and formed one party, and these parties divided ideologically and intellectually into four main directions and streams as followed (Sweis 219: 2004) Islamic trend, leftist direction, national trend, and intermediate direction, and it is called (conservative or national) ), and this map was formed through a series of operations after 1989 such as (Rawabdeh, 1999, pp. 44-45).

Left and nationalist parties move to engage in activity openly. Some Palestinian factions turn into political parties that conduct their activities openly, and the Muslim Brotherhood's attempt to create an Islamic political movement by absorbing independent Islamic personalities within the Islamic Action Front. To bring out a political party that consecrates the legitimacy of the Islamic Action Front and is not affiliated with the Muslim Brotherhood, which considers itself an all-inclusive movement. The emergence of new Islamic parties with a moderate approach, and the disappearance of other Islamic parties from the political arena because of the ban, such as Hizb ut-Tahrir, and the tendency of political and economic personalities and tribal leaders to form political parties, which is called "centrist parties, and the separation of groups and partisan parties from their original parties, forming new parties, and merging some of them into one party - and forming and creating a group of weak and small parties since the issuance of the Parties Law 1992, due to the development of the peace process.

\section{Factors of the Evolution of the Islamic Trend}

The development and growth of the Islamic trend in Jordan came due to several factors, the most important of which are the national and Nasserist experience's failure, especially in presenting a role model reflected in its Arab and internal spread. The importance and attractiveness of the Baathist nationalist parties to governance declined. The economic and social crises deepened, and the Islamic trend found a substantial opportunity for it after the Islamic Revolution's victory in Iran. And found a field of struggle for him and more significant popular support after Islamic organizations participate in the confrontation and jihad against the Israeli occupation. At a time when the collapse of the Soviet Union launched a comprehensive review of socialist thought, which affected the left parties, especially Marxism (Hourani, 127: 2004), and the internal and external pressures that the political system and Islamic movements were exposed to, allowed a comprehensive review of political participation and democratic transformation to face these pressures. Also, the development of the Islamic current's relationship with the United States during the Cold War, its relationship with the Jordanian political system, and the lack of confrontation between the two parties, in many cases, the alliance and consensus between them worked to direct the Jordanian citizens to deal with the Islamic trend more than it deals with other political currents left and nationalism that conflict with the orientations of the Jordanian regime (Musalhah, 1990).

Also, the safety distance in which the Muslim Brotherhood moved away from the system enabled it to maintain the coherence of its organizational structure and its growth and preserving its image as an opposition movement, which enabled its supporters to distance themselves from the authority of the security services and the public turnout to join the ranks of the Islamic trend. Therefore, the requirements of the Cold War and facing the communist expansion (Al-Rantawi, 91: 2004), the intermediate nature of the Islamic movement, and the nature of the tolerant Jordanian regime and containing it to oppose it, and it has made coexistence and harmony between the Jordanian regime and the Islamic movement a distinct phenomenon since its inception, enabling it to face all challenges to its legitimacy and continuity. 
During the development process, the relationship between the two parties faced some tension and tension after promulgating the Parliamentary Elections Law of 1992, the Single Voice Law.

This is what the Muslim Brotherhood World Observer and Secretary-General of the Islamic Action Front expressed in that the government targets the Islamic movement, and the target is opposition to official policy. Since 1994, the contrast between official policy and the pulse of the Jordanian street began. Where the government started to remove the Islamic movement from influential positions to adapt the Jordanian reality to its political bodies and parties to harmonize with it (Al-Thunaibat and Mansour, 2003), it may be because the Islamic Action Front attempts to control political action because of what is considered to be its increasing influence and power in the Jordanian street. It may also be because of the contradictory positions on political events in the region, American wars on the region and Islamic countries, and the positions of the anti-peace movement, and the impact of Hamas and the Palestinian uprising on the Jordanian scene, the demographic composition of the Islamic movement, the expansion of its influence bases in the Palestinian camps, the weak political and intellectual currents on the Jordanian scene, and the absence of a recent Jordanian methodological view of how to deal with the Islamic trend. But despite that, the Islamic movement maintained a policy of coexistence with the Jordanian state and did not resort to violence Or opposition that exceeds the limits of difference, Which enabled it to succeed on the Jordanian scene and to maintain its continuity and legitimacy in facing the challenges facing the political system.

\subsection{Factors for the Success of the Islamic Trend (Al-Hajj, 2004: 77-84)}

The Islamic movement in Jordan is an exception to Islamic action in the world. And what the movement reached from an exception in Jordan came from the regime and not from the government, and it is an integration between the system and its references, and the jurisprudence of the Islamic movement and its references (Al-Adwan, 2008, pp. 355-357). The Islamic movement is also based on its principles and philosophy from Islam to which the entire Jordanian people belong. Muslims belong to it in terms of belief and civilization, and Christians belong to it in terms of civilization, heritage, and history.

This is one of the constants of the Islamic movement. The movement is also distinguished in its clear and consistent position on the Palestinian issue in particular and on the homeland and the Islamic nation, which all Jordanian society sectors are concerned about. It also adopts the people's issues and senses their pain, and hopes to object to all laws and practices that harm the interests of citizens or limit their freedoms guaranteed by the constitution according to their opinion. It is distinguished in moderation in dealing with successive governments after the establishment of several centrist Islamic parties such as the Islamic Wasat Party and the Dua movement. Its belief that change and reform do not come through violence; its opposition is based on erroneous governmental practices and is not against the system and the constitution, and moved away from the atonement style, and its belief in the strict organization and comprehensive educational approach in raising individuals, which made it immune to all attempts to dismantle and get out of crises with minimal losses, the diversity of its political, social, educational and charitable work methods, and her distinguished practical position in promoting national unity and rejection of regional and sectarianism, and the movement's distinct position on women and its Islamic view of her, it also provided the appropriate conditions for advancing women's political action in terms of membership in the party, the practice of activities, and women's access to leadership positions in the Islamic Action Front party before the Shura Council, as well as the position of the Islamic movement from other directions, either non-Muslim minorities or parties whose ideology is at odds with them.

We find that the Islamic trend is the most extensive political current in the Jordanian arena. Coexist and supported the Jordanian regime in all challenges, pressures, and stages that it passed through. It is considered that political and party pluralism is a modern, democratic appearance dealt with political parties by the Islamic Action Front party, which was established to be the political arm of the Islamic movement. The Islamic trend also dealt with a multi-party system: And other political trends, which ideologically contradicts it through the party coordination committee of opposition parties, which is considered the most stable and the longest-lived among the party coalition experiences and its ability to survive, despite the sometimes great differences between the parties affiliated with this committee. This committee has succeeded internally toward domestic issues such as the position on the election law, and the Law of Parties, Meetings, and many other issues (Madhaneh, 2004). Despite the significant differences in this committee's frameworks, the Shura Council president (Arabiyat September 2004).

In the Islamic Action Front Party, he says that it is "in the principle that we are different and there is no harm in that, but when we meet on an everyday basis between the parties, we do a unified mission, and if we are not different, it means that we are one party. And we are not like that, and each party performs its role according to 
its diligence, they meet on common public issues.

\subsection{The Map of Multilateral Islamic Parties}

The Muslim Brotherhood: (Al-Adwan, 2007: (97-131)).

The Muslim Brotherhood in Jordan can be considered an extension of the Muslim Brotherhood in Egypt, which was founded by Hassan al-Banna in 1928 in Ismailia, Some Jordanians joined it and became members of the Brotherhood's Shura Council in Egypt, and they began transmitting the group's ideas to Jordan.

The start of the formation of the Muslim Brotherhood in Jordan on November 19, 1945, came after a decision by the Jordanian Cabinet, published in the Al Jazeera newspaper in its 1074 issue, at its session on January 9. 1946. To some Jordanians, establishing an association in eastern Jordan called the Muslim Brotherhood, and the group's public center was opened under King Abdullah I (Gharaibeh, 1997: 47). It seems that King Abdullah was convinced of the Muslim Brotherhood's idea in light of the growing left-wing political opinions; he expressed his appreciation for the leadership of the group and the views it holds. And he offered a group leader in Egypt a ministerial position in the Jordanian government and granting the title of Bashoy to their leader Hassan Al-Banna, but they apologized for not accepting the offer in a letter addressed to King Abdullah (al-Husayni 1955, pp. 146-147). But they apologized for not accepting the offer in a letter addressed to King Abdullah (al-Husayni 1955, pp. 146-147).

The group has established a basic system that defines its basic principles and its general means, Published by Al-Jazeera newspaper in its edition1100 in 1946. In (Al-Ubaidi), it says work on forming a generation that correctly understands Islam and applies it to him and calls for it. And the call to consider Islam as a basis for the Arab renaissance, because it contains flexibility and tolerance that works everywhere and every time, and spreading Islamic culture and raising generations in an Islamic way, and defending Islamic beliefs and the etiquette and civilization of Islam. It was not mentioned about the Muslim Brotherhood starting its engagement in politics or political and revolutionary work as is known about Islamic groups in other countries. The reason can be explained by the care that King Abdullah and later King Hussein gave them, where the Jordanian regime worked to protect them in Jordan, especially after the group in Egypt was persecuted, and on the other hand, the group stood with King Hussein in the events of the fifties and was one of the supporters of the regime (al-Kilani, 1990, pp. 8-10). The group remained openly active even after the parties' dissolution, as the government considered them a group and not a party (Al-Hajjaj, 2001, pp. 97-131).

After the unity of the two banks, the group developed in its social and organizational structures after the new members joined from Palestine, as it transformed from an Islamic organization for preaching and reform into a political group with a reform, social and general program (Gharaibeh, 61: 1997), it gradually transformed to practice political activity openly and freely. And new elements join their ranks and take a policy of appeasement mixed with dissatisfaction - sometimes - towards government policies (Cohen, 206: 1988).

With the beginning of the spread of ideological parties, the Muslim Brotherhood became one of the most critical political poles on the Jordanian political scene, and the parliamentary elections that established the first partisan political pluralism in Jordan's political history in 1956 may have sparked controversy among the group, where the majority saw that entering the elections helps spread the Islamic call through the Parliament, and a way to confront colonial danger and defend national interests, while others believe that any percentage of victory does not achieve the leadership of Jordan to implement Islamic law, it is rejected (Mansour, 1992, pp. 64-65), the Brotherhood did not stand firm in their relationship with the Jordanian system and Jordanian or Arab government policies, as their positions fluctuated between support in the event that government or Arab political positions were consistent with their goals, and between hostility and opposition in the event that the positions of these parties become contrary to their principles and goals, and little of what they were standing in the middle of political and social events.

The Muslim Brotherhood focused on public freedoms and criticized the government for restricting freedoms to any individual or party, and defending the rights of citizens, workers, and youth (the Islamic struggle, 1954), and demanded the release of press freedoms, and criticized the suspension of newspapers of all kinds.

Therefore, the movement contributed to developing the political process on the Jordanian scene, the success of multi-party politics, political participation in parliamentary life, and political pluralism. And this is in response to internal and external pressures and crises that the political system and movement suffered to preserve its continuity and legitimacy.

\subsection{Islamic Liberation Party (Al-Adwan, 2014: 11-115):}

Hizb ut-Tahrir appeared after a group of religious activists defected from the Muslim Brotherhood in 1952. As a 
religious group, its references are Haj Amin Al-Husseini (Al-Ubaidi, 1993, p. 162) and in line with political development. A group of founding members applied to the Ministry of Interior to license a political party on November 17, 1952. However, the request was rejected by the Ministry of Interior due to its conflict with the Jordanian constitution, as the party's basic system denies the system of monarchy based on inheritance, That is, the regime of the party indicates its desire to reach power through religion (Al Madi \& Al Madaa 598: 1959). And the party tended to take advantage of the Ottoman Associations Law to license, as they attempted to challenge the decision of the Interior Minister at the High Court of Justice (Cohen 19: 290), but the government did not agree.

Hizb ut-Tahrir set its platform on several principles, the most important of which (Hizb ut-Tahrir concepts 1953: 66-88). The caliphate is a general presidency for all Muslims in the world to establish the provisions of Islamic law. The establishment of a caliph imposed on all Muslims in all countries of the world (the view of the Liberation Party in the caliphate, d. D.). Moreover, calls for the establishment of the Islamic State, fighting colonialism and all partisan ideas, and carrying Islam as a message to the world and the leadership of the nation, the struggle with unbelief, its systems and ideas.

Hizb ut-Tahrir believes that the Islamic countries, including the Arab ones, govern the infidelity regimes and their provisions, and therefore it sees the Arab regimes as illegal and linked to western colonialism. Despite the government's resistance to Hizb ut-Tahrir in a way that might be more severe than the ideological parties at that point, the party started its activities from the mosques in Friday meetings. However, the security authorities pursued preaching and imposed restrictions on his activity, turning the party into a system called the "episodes" to organize its ranks (Harris, 1959: 83). Hizb ut-Tahrir participated in the parliamentary elections since 1951 and established with the Jordanian parties the first political pluralism in the history of Jordan in 1956. And The establishment of the first coalition government on a party basis and the party member in Parliament criticized the government's position on public freedoms and exceptional laws. They justified their participation in the elections to make the people heard the voice of political Islam from the pulpit of the House of Representatives (Adwan, 2008, pp. 355-356).

Therefore, he rejects political pluralism, political participation, and democracy and believes that democracy is an infidel Western system with no relation to Islam. Whereas Western democracy is outside Islam, and all that results from democracy in terms of pluralism and freedoms in all its forms is prohibited and rejected. It is forbidden to deal with it and believes that the Islamic parties that adopt the concept of democracy and political pluralism violate the legal provisions. Thus, any Jordanian party that has been licensed according to the Jordanian Parties Law and according to the Jordanian constitution are sinful, and infidel parties (Mansour, 1992, pp. 94-95); Hizb ut-Tahrir has tried to penetrate the ranks of the armed and security forces to recruit members. However, their invitation did not find acceptance except in some circles of the National Guard in the West Bank, which explains that the activity of Hizb ut-Tahrir in the West Bank is stronger than in the East Bank, especially after the Muslim Brotherhood's support for Hizb ut-Tahrir's candidate to thwart the success of any Communist or Baathist (Al-Kilani, 1990, pp. 94-95), and Hizb ut-Tahrir adopted to publish its ideas and policies, or its opposition to the government and the regime through its numerous publications, publications, statements, and some booklets that are exposed to political positions. It was not published regularly (notions of Hizb ut-Tahrir: 88), despite what Hizb ut-Tahrir and its members were subjected to. However, it left a clear political impact in the fifties, and he contributed to the development of political action and party and political pluralism in Jordan despite his lack of conviction it. To this date, he remains at his position of denying pluralism and democracy and focusing on the caliphate.

\subsection{Islamic Action Front Party}

After 1989 and the transformation of the political system in Jordan, the Islamic Action Front party was established, which is the Islamic trend's backbone, where the Muslim Brotherhood is the party's reference. The Islamic trend includes independent Islamist movements, parties, and figures. The most important of them are the Muslim Brotherhood and the Islamic Action Front party, which is almost the entire Islamic movement.

After the issuance of the Political Parties Law in 1992, and to work on the political scene like other parties, the Muslim Brotherhood and several independent Islamists established a political party (the Islamic Action Front Party) on 8/12/1992, in which Brotherhood leaders assumed leadership positions in the party, which led to a split in the party (Al-Hourani, $1993+1997)$. After the resignation of some members and independents due to the abuse of seats allocated to them in the party's Shura Council, among the group's leaders, and the absence of clear borders between the Muslim Brotherhood and the Islamic Action Front party. A number of the Muslim Brotherhood also resigned from the party because of organizational differences and the party's opposition to 
nominating members who wish to run in the parliamentary elections; in 2017, a group of party leaders withdrew and formed a new party called (Zamzam). Nevertheless, the Islamic Action Front remained strong as a political movement. As the Islamic Action Front separated from the Muslim Brotherhood in August 1994 (Al-Fatlawi, 1996: 230), to announce himself as "a contemporary political attempt to find a flexible Islamic action template that is inclusive of all citizens and believes in Islamic thought and culture" (Al-Khatib, 2004: 141), where the party's stance towards political participation is consistent with being a political party that raises the slogan of democracy and political pluralism (Al-Farhan, 1996) in the stage of transformation for democracy and political pluralism which resulted from internal and external pressures and challenges facing the political system and political parties.

The party derives its principles from Islamic thought. Its general objectives are to establish the method of Shura and democracy and to defend human dignity and rights, and freedoms in general. As for its own goals, it stipulates achieving the principle of responsibility for all consolidating the pillars of the Shura, democratic practice, ensuring political pluralism and protecting human rights as affirmed by Islam, and establishing legislative guarantees that guarantee this from the perspective of respecting the constitution and the rule of law (the political system of the Islamic Action Front Party 1995: 5-6). Therefore, the Islamic Action Front Party became a formula for adapting to the law of political parties. And a means of institutional political action that combines the Muslim Brotherhood with independent citizens who want to work in politics without participating in the Brotherhood. It is a Muslim Brotherhood party operating financially and organizationally, which contributes to coordination and integration with the Muslim Brotherhood, and serves within the strategic framework of the group's goals (Al-Gharaibeh, 1996, pp. 145-146).

After the party has completed its systems and regulations, it ranks its priorities and interests (Al-Adwan, 2013, pp. 222-223), on Jordanian affairs first and Palestinian affairs secondly, and Arab affairs third, and Islamic affairs fourth. In theory, its primary concern is humanitarian issues, and its internal political program is concerned with the political field and public freedoms.

Partisan and political pluralism is part of the democratic process. Therefore, the party focuses its attention on establishing Shura and democratic education in educational institutions and universities. It seeks national unity and national security. The party also seeks economic reform. Its social program focuses on family cohesion and protection and equality between men and women. In his cultural program, he focuses on Islamic education and creating an educated Islamic generation capable of keeping pace with developments in the world and getting them used to practice democracy and Shura. As for the party's experiences with pluralism and democracy, Yitzhak Al-Farhan, one of the party's leaders, believes that there is no sensitivity to using the term democracy as long as the meaning is the essence of Shura.

The party is also keen to consolidate the biography of Shura and democracy in Jordan, cooperate with all political forces in this field, and affirm everyone's right to political participation. It affirms the principle of the right to participate in the executive authority, or constructive political opposition, according to the public interest and according to the legal policy's requirements. The party has also developed expertise in Islamic political action on the Jordanian scene to set an example in the region. It also affirmed effective participation in the parliamentary elections to reinforce democracy and pluralism's basic meaning.

From the preceding, we find that the Islamic Action Front Party is an Islamic party, in response to political changes and developments on the Jordanian scene (Clinics 1996, pp. 142-165). The party represents the Islamic movement on the political scene, and it adheres to Islam as a belief, law, and life system. The party applied the principle of Shura and participation within its ranks. Simultaneously, a formation came based on the political parties' law, commitment to the constitution, and the national pact, which allowed it to play its role in political life. And openness to most groups of society and the political system. It emphasizes political pluralism and democracy within Islamic principles as a strategic choice, respects the freedom of the other opinion, stifles freedoms, and supports the policy of reform.

\subsection{The Arab Islamic Democratic Movement (Doaa)}

The first appearance of this movement in 1989 was the beginning of the transition to democracy and political pluralism. The political system interface from internal and external crises led to democratic transformation and multi-party politics and obtained a license on April 13, 1993.

The movement believes in the national idea based on Islam and Arab unity and does not see any contradiction between them, and each supports the other. The movement considers itself representative of the rational stream within the Islamic currents, and it is based on its necessary intellectual foundations (Al-Adwan, 2013, pp. 224-257). The dialectic of Arabism and Islam means rebuilding national thought on Quranic foundations that 
lead to the fact that the Arab nation is a Quranic necessity. The dialectic of democracy and Shura is Islamic democracy: "It is the political project of the Doaa movement" (Al-Assaf 203: 2003). The dialectic of reason and text, i.e., the method it uses in research, whether in the religious text or any objective text outside the awareness, Islamic economic doctrine, and the Islamic-Christian relationship. Therefore, the movement is considered in its political behavior, an independent Jordanian movement, which came from the trend of the political system to involve civil society institutions in addressing the challenges and pressures facing them. It works in the Jordanian community and outside it and is not subject to any ideological or political influences or suggestions that are not consistent with its proposals in various aspects of Jordanian life. It is based on several intellectual foundations (Ayyad, 1992, pp. 25-41). The Secretary-General of the Dua Party says that his movement differs from the Islamic parties in its attitude towards Arab nationalism, its attitude towards reason, and its relationship to the text, and from democracy and pluralism, and its cultural and civilizational position, and its position on women (Haddad, 1994, pp. 83-84).

The charter of the movement stipulates that the civilizational transformation that Jordan witnessed is distinct, foremost among which is the "return of life. Parliamentary and political pluralism (Aleadwan 231: 2014)." and the movement is based on its external and internal political behavior based on the people's right to self-determination, and freedom, equality, and justice are considered sacred value, and that Jordan is part of the Arab world (Hamarneh 69: 1995). In the Jordanian-Palestinian relationship, the movement's charter sees Jordan as the east wing of the land from the west of the river, and that the pillars and intellectual bases our people in its wings and the people of our entire nation emphasize the single civilized entity with its social, cultural, psychological, historical and geographical dimensions, And Palestine is a Jordanian issue before it is the issue of Arabs and Muslims (Al-Adwan 231: 2014); as for a peaceful settlement, the movement supports the peace process, unlike the Islamic Action Front party, and considers it a long-term gift between Islam and the Zionists. Imposed by the imbalance of power, it ends as soon as the balance becomes in favor of Muslims and criticizes Israel's normalization.

As for democracy, the movement sees it as "a normal human tendency towards instinct that God has broken the people, which is an earthly attempt to approach the values of heaven granted to man (Doaa Movement Charter 1993, pp. 46-47)." and it will struggle democratically to reach Parliament to form a government that implements its political program and implements its ideas set out in the Charter. As for political pluralism, the movement has its concept of pluralism. It stems from its adoption of pluralism from the perspective of the human difference in heredity and the environment that produces diversity in the intellectual vision. Thus, it supports political pluralism (Doaa publications), being a sub-issue, the Qur'an did not mention it in detail. It is a sub-worldly matter that was not detailed. Therefore, the movement affirms the legitimacy of political pluralism and democracy, which depend on a civilized dialogue method, away from nervousness and the confiscation of the other opinion.

\subsection{Islamic Center Party}

The party is considered one of the centrist Islamic parties, which was formed from most of the Muslim Brotherhood members, who were split from it. And those who have held political positions in the state and representative positions (names of secretaries and addresses of political parties, a bulletin from the Ministry of Political Development); The Islamist Center Party obtained the license on December 29, 2001, as a result of the political system's trend of democratic transition and political pluralism. And despite the widespread debate about the founding of this party, some observers believe that the new party means the birth of a party that adopts Islamic liberalism as an approach and behavior in the face of fundamentalist Islam. The party believes that the Shura based on the principles of Islam does not abolish democracy as the political action mechanism for the transfer of power within the framework of the constitution and law; the party believes in intellectual dialogue as a basis for political action within the party and highlighting the importance of academic freedom (Khatib 9: 2005).

The party believes that Islam is the ideology of the nation and the curriculum that organizes its life. And this is one of the main principles of the party's ideology (Basic Law of the Islamic Center Party, 2001). As for the concept of the Democratic Party, it believes that democracy should be comprehensive in terms of life and not be restricted to the political aspects. And the party believes in the necessity of involving members of the Jordanian society and its slides in leadership or having a role in planning and implementation. It also believes that the Islamic religion opposes extremism and intolerance, respects pluralism, and calls for moderation.

The party considers that (Al-Wasat Al-Islami Party, D.T .: 18-19) intellectual pluralism is one of the foundations of life and mercy so that the development and the integration of human giving continue." and believes that "all 
people through the concepts of Islamic moderation who express other perceptions of the other become a companion of the path to which we progress with the good and guidance we have, and we seek to listen to his thinking and perception at the level of individuals, institutions, nations, and civilizations, and it believes that the Shura based on the principles of Islam does not abolish democracy as the political action mechanism for the transfer of power within the framework of the constitution and the law. It believes in intellectual dialogue as a basis for political action within the party and highlighting the importance of academic freedom (Basic System of the Islamic Center Party, 2001).

The party believes that Islam is the nation's ideology and the curriculum that organizes its life, and this is one of the main principles in the party's thought. And regarding participation in political work, the party does not believe in boycotting, but instead focuses on the involvement in political work and is the basis, and boycotting of political action is not possible unless participation becomes impossible based on integrity, justice, and equal opportunities. Democracy and political pluralism are political action mechanisms and the transfer of power within the constitution's framework and the law. And one of the party's principles is to reject differences and seek agreement, understanding, tolerance, and truth that no one owns. It believes that Jordanians have the same rights and have the same duties and take positions according to efficiency. The party also stresses the importance of freedom, human dignity, and inalienable rights, the promotion of intellectual freedom, acceptance of the other opinion, and all rights according to Islamic Sharia and what the constitution stipulated, where the party emphasized the role of women in society and the necessity of involving them in political work, preserving the independence and integrity of the judiciary, and launching press freedoms. In 2004, after the new political bureau (Al-Adwan, 2014, pp. 233-234), the party recognized that Partisan life in Jordan lives in a state of vulnerability due to personalization and opportunism. And the absence of mass leaders, moving away from people's concerns and the street's pulse, being satisfied with slogans, and not advancing realistic reform programs. In addition to other reasons, including campaigns to question parties and party work, and the persistence of power practices that terrify people from joining parties, insist on the one-vote law and the law of meetings surrounding mass activities.

\section{Challenges Facing the Islamic movement (Al-Adwan, 2013: 280-286):}

Some Islamic parties, especially the Islamic Action Front and the Muslim Brotherhood, suffer from some substantive challenges, despite some moderate Islamic parties' denial of these challenges. These challenges ruled the political conditions that the political system went through and practiced in Islamic parties' face, including: (Researchers Group, 1999).

A. Financial challenges: The legislation and laws are involved in determining parties 'financial resources, limiting the diversification of funding sources, and how these funds are spent. And this is considered interference in the affairs of the internal parties rather than government censorship, the most recent of which was the government's hand over the Islamic Center Charitable Society.

B. Political challenges: The process of political formation that successive governments practiced through the various means of building created a negative view of parties in citizens' eyes, and distorting the image of parties and their affiliates, exposure to parties directly, and the constant threat of these parties. And attempts to restrict Islamic political parties and political pluralism by governments after 1989 through the law of meetings and the prevention of protests and party marches, and encouraging splits, and election laws.

C. Legal challenges: (Barakat, 1992: 298) Giving the executive branch broad powers at the expense of the legislative authority, and this has the effect of developing laws and legislations that limit the work and political participation of Islamic parties, or the exercise of their political activity, like some articles of party law, and influencing the ability of Islamic parties to be represented in Parliament by setting the election law that provides for a single vote, and the proportional representation system excluded the list system.

D. Security challenges: Successive governments have resorted to confronting the Islamic opposition and fabricating issues against some of these parties and their leaders. Arresting some of them, confiscating others' freedoms, And the pursuit of some of its members of citizens and institutes and universities, and there may be external pressure on the political system to confront Islamic movements. The possibility of it resorting to unlawful methods in achieving its goals, which constitutes a factor of concern and fear for the political system, especially after the events of September 11, 2001, in America, and since the Islamic movement is an ideological movement that depends on the reason for its existence on its principles, and the flexibility to achieve its strategy and realism in taking its positions, so that the fundamental challenge facing the Islamic movement is its ability to balance between preserving its principles and not neglecting them, and the pragmatic political dealings in achieving and downloading these principles a reality on the 
ground (Safadi, 2007).

\section{Conclusions}

- The Islamic movement considers political pluralism as a matter of legitimate interest and political pluralism practiced by the Islamic movement, which came as a result of external and internal pressures faced by the political system a year later1989, and that paved the way for a multi-party system after the promulgation of the Parties Law of 1992: it resulted in pressures on the Islamic movement and political challenges by the political system as it faced international Islamic movements, external political challenges have made political pluralism an option for the Islamic movement in Jordan, which has been allowed by the political system, which has contributed to the stability of the Islamic movement and the political system.

- The emergence of some moderate Islamist parties helped to engage in the political process, reducing exaggeration and accepting political pluralism, and change the attitudes of some Islamist groups, especially the Islamic Action Front, towards democracy and pluralism.

- Some Islamic parties, especially Hizb ut-Tahrir, rejected democracy and political pluralism and considered it an infidel system that contradicts Islamic legal principles despite its participation in the multi-party elections in 1956. The Islamic movement, except Hizb ut-Tahrir, applied the pluralistic system and the foundations of participation and power exchange within its organizational framework. Thus, it represents a façade and precedent for applying political pluralism in all civil society organizations and other partisan frameworks. This is not evidenced by the Islamic movement's participation in the legislative elections in many of its stages.

- Despite what the governments did to amend legislation and the election law in 1993, it restricted the Islamic movement's participation. However, the moderation taken by the Islamic movement generated a political culture that does not refuse political participation or partisan political pluralism within the legal rules and in a manner that does not contradict the Qur'an and Sunnah.

- The Islamic movement has taken moderation in rejecting exaggeration in religion and dealing with others. This moderation does not mean neglecting the faith, the provisions of Sharia, and the ethics of Islam and its system; the Islamic Action Front has participated in the Coordination Committee of Forces and National and Islamic Parties with which it differs in belief and goals. Also, some of the audits carried out by the leaders of the Islamic movement between each stage and stage enabled them to move away from extremism and political extremism and reject violence and not resort to it as one of the main principles of the Islamic movement in Jordan, enabling it to engage in the political process. Islamic political parties exercised noticeable transparency in managing their internal affairs and viewed party work as an entry point to reform and political pluralism. Therefore, the Islamic parties adopted the method of moderation in their political action and openness to the state's components as a result of the state's tolerance and openness in many times to the Islamic trend. On many political issues, this trend has enabled it to integrate into political action by establishing Islamic political parties, allowing it to engage in Jordan's political process. Islamic parties and their presence at present are a necessity for Islamic societies, and their progress is necessary for freedom of opinion in these societies, and it is a guarantee that the rulers will not be alone with the people.

\section{References}

Al-Adwan, A. (2007). Political Pluralism in the Hashemite Kingdom of Jordan (1921, 1989, Part 1). Entrepreneur Center for Studies and Publishing, Amman.

Al-Adwan, A. (2008). Political Pluralism in the Hashemite Kingdom of Jordan (1989, 2009, Part 2). Entrepreneur Center for Studies and Publishing, Amman.

Al-Adwan, A. (2009). Political Pluralism in the Hashemite Kingdom of Jordan (Part 2). Al-Raya Publishing House, Amman

Al-Akour, A. (2004). Political Islam and Contemporary Challenges, (in) Jordanian Political Parties, Reality and Ambition. Acts of a Conference, Al-Quds Center for Political Studies, Amman.

Al-Dajani, A. (1989). Political Pluralism in the Arab Islamic Heritage (ibid.). In S. E. Ibrahim (Ed.), Political Pluralism and Democracy in the Arab World. Arab Thought Forum, Amman.

Al-Dajani, A. (1990). Diversity Unit and Arab-Islamic Civilization in an Interconnected World. Dar Al-Mustaqbal Al-Arabi, Cairo. 
Al-Fatlawi, A. (1996). Social and Political Stability in Jordan, An Analytical Study in the Light of the Concept of Balance (Unpublished Master Thesis). University of Jordan, Amman.

Al-Faouri, M. (2017). Islam's Moderation in the Face of Extremism. The World Forum on Moderation.

Al-Farhan, I. (1996). The Islamic Movement and Political Work in Jordan during Half a Century, in Parties and Political Pluralism in Jordan.

Al-Farhan, I. (1996). The Islamic Attitude towards Political Participation. Literature Series of the Islamic Action Front Party, (6), Amman.

Al-Farhan, I. (1996). The Islamic Attitude towards Political Participation. Al-Nadwa Magazine, 7(1). Abdul Hameed Shoman Foundation, International Affairs Association.

Al-Hajjaj, K. (2001). History of Jordanian Political Parties, 1946 1970. Amman.

Al-Hajj, M. (2004). The Islamic Current in Jordan, (in) Jordanian Political Parties. Reality and Ambition, (Seminar) Jerusalem Center for Political Studies, Jordan

Al-Hamad, T. (1992). Ideological studies in the Arab case. Dar Al-Taleea, Beirut.

Islamic Center Party. Idea and Curriculum (2nd ed.). Amman, d. T.

Al-Hourani et al. (1993). The Islamic Action Front Party. New Jordan Center, Amman

Al-Hourani et al. (1997). Islamic Movements and Organizations in Jordan. (Collective Author) New Jordan Center, Amman

Al-Hourani, H. (2004). The March of Jordanian Party Life, Reality, Problems and Prospects. The Guide to the Political Party, Amman, 1995.

Al-Husseini, I. (1955). The Muslim Brotherhood, The Major Modern Islamic Movements (2nd ed.). Dar Beirut.

Al-Khatib, N. (1983). Political Parties and Their Role in Contemporary Systems of Government. Dar Al-Thaqafa for Publishing and Distribution, Cairo.

Al-Khatib, J., \& Walid, K. (2004). Arab political parties - the general scene (in), political parties in the Arab world, the current reality and the future prospects (conference activities). The Jerusalem Center for Political Studies, Amman, p. 181.

Al-Khatib, J. (2005). The Political Path of the Islamic Movement in Jordan. Unpublished Research, Al-Quds Center for Political Studies, Amman.

Al-Kilani, M. (1990). Islamic Movements in Jordan. Dar Al-Bashir for Publishing and Distribution, Amman.

Al-Kuwari, A. (1993). The Concept of Modern Democracy, Common Principles of the Constitution. The Arab Future, (173), July.

Al-Mady, M., \& Al-Mousa, S. (1988). History of Jordan in the Twentieth Century. Al-Muhtaseb Library, Amman, Jordan.

Al-Rantawi, O. (2004). The Islamic Current in Jordan, Present Problems and Future Prospects (in) Jordanian Political Parties, Reality. Ambition, Jerusalem Center for Studies.

Al-Rabee, F. (2004). Democracy between Intellectual Rooting and the Political Approach. Al-Hamid Publishing and Distribution House, Amman.

Al-Rawabdeh, A. (1999). Challenges of building a democratic political structure in Jordan (in) political parties and pluralism in Jordan. A symposium of the Abdul Hameed Shoman Foundation, Amman

Al-Safadi, H. (2005). Manifestations of the concept of moderation in some Islamic movements (in) the moderation of Islam between thought and practice. "Working Papers of the First Conference, Amman 2004", The Moderation Forum for Thought and Culture, Amman.

Al-Sahrani, A. (2000). The Struggle of Nations between Globalization and Democracy (p. 62). Dar Al-Nafees, Beirut. Abdul Latif Arabiyat, former General- Secretary of the Islamic Action Front, a political seminar on parties' law, Al-Rai Newspaper, November 26, 2009.

Al-Tamawi, S. (1979). The Three Powers in Arab Constitutions and in Islamic Thought. Arab Thought House, Cairo.

Al-Thunaibat, A., \& Mansour, H. (2003). A meeting with the general observer of the Muslim Brotherhood and the Secretary-General of the Islamic Action Front. Al-Sabeel newspaper. 
Al-Zoubi, S. (1995). Political Parties and Parliament The Jordanian Experience (in) The Guide to the Political Party (Workshop) New Jordan Center for Studies. Amman.

Amara, M. (1997). Islam, Pluralism, Difference, and Diversity in the Context of Unity. Dar Al-Rashad, Cairo.

Arabiyat, A. (2009). Milestones of renewal in the Islamic movement in Jordan (in) political parties and pluralism in Jordan (symposium works). Abdul Hameed Shoman Foundation.

Arabiyat, A. (2004). The concept of the Islamic movement, political pluralism. Al-Rai Newspaper.

Assaf, N. (1994). Jordanian Political Parties 1992-1994. Previous reference.

Ayyadat, Z. (1997). The Islamic Movement and Political Participation. (in) Islamic Movements and Organizations in Jordan (Collective Author), New Jordan Center for Studies and Sinbad House, Amman

Ayyad, R. (1992). Political currents in Jordan and the text of the Jordanian National Charter. National Press, Amman.

Barakat, S. (1992). Arab parties and their role in democratic transformations. The Arab Future, Q14, No. 155.

Cohen, A. (1988). Political Parties in the West Bank under the Jordanian Regime, 1949-1967. Translated by Khaled Hassan, Al-Qadisiyah Press, Jerusalem.

Danleavy, P. (1982). Liberal Democracy, 14-15. R. Dahl, Diploma of Pluralist Democracy, Autonomy Versus Control. New Haven: Yale University Press

Depstein, L. (1967). Political Parties in Western Democracies. New York: Pregerinc.

Desouki, I., \& Al-Ghannam, A. (1973). History of Political Thought. Dar Al-Najah, Beirut.

Doverje, M. (1992). Political Institutions. Translated by George Saad, University Foundation for Studies and Publishing, Amman.

Eldersveid, S. (1964). Political Parties: A behavioral analysis. Chicago: Bond McNally.

Haddad, Z. (1994). The file of political parties in Jordan 1919-1994. Amman, d. N.

Hamarneh, M. (1995). Civil Society and Democratic Transition in the Arab World Project. Dar Al-Ameen for Publishing and Distribution, Cairo.

Hassanat, A. (1995). The Election Law and the Democratic Process Post Election Seminar A Discussion of Jordan 1992 Parliamentary Election. Amman Jordan. Alurdon Al- Jadid Research center

Hizb ut-Tahrir concepts. (1953). Hizb al-Tahrir Publications. Independence Press, Beirut.

Hizb ut-Tahrir's Approach to Change. (1989). The representative of Hizb ut-Tahrir speech at the Muslim Students Association Conference. Missouri, USA.

Mansour, A. (1992). Attitudes of some Islamic groups and parties in Jordan regarding democracy and political pluralism. The previous reference.

Masalha, M. (1990). The Political Party Experience in Jordan, An Analytical and Comparative Study. Dar Wael, Amman.

Mudiya, N. (2004). An opinion on the coordination experience, opposition parties. Al-Rai newspaper.

Prince Hussein bin Talal speech. (1989). At the symposium's opening on political pluralism and democratic transformation in the Arab world. (Prepared) by Saad Eddin Ibrahim, Arab Thought Forum, Amman, p 9.

Sweis, S. (2004). Arab political parties and human rights, focusing on Jordanian parties. (Conference) Jerusalem Center for Political Studies, Amman.

Sweis, S. (2004). Arab political parties and human rights, focusing on Jordanian parties (in) political parties in the Arab world, the current reality, and the future prospects. The Islamic Center Party's statute.

Thabet, A. (1990). Political Pluralism in the Arab World, a beneficial transformation and cloudy prospects. The Egyptian Authority.

Zalloum, A. (1990). Democracy is a disbelief system. Publications of Hizb ut-Tahrir.

The Charter of the Arab Islamic Democratic Movement, Duaa. (1993).

A view of Hizb ut-Tahrir in the caliphate. See Caliphate, Hizb ut-Tahrir publications. Modern Press, Kuwait, d.

The basic system of the Islamic Wasat Party 2001. 
The statute of the Islamic Action Front Party.

The basic system of the Islamic Action Front Party (1995).

Political Parties Law, No. 32 of 1992.

The Islamic Struggle, No. 2, August 17, 1954.

\section{Copyrights}

Copyright for this article is retained by the author(s), with first publication rights granted to the journal.

This is an open-access article distributed under the terms and conditions of the Creative Commons Attribution license (http://creativecommons.org/licenses/by/4.0/). 